\title{
Enhancing the performance of Transmission Lines by FACTS Devices using GSA and BFOA Algorithms
}

\author{
N. Karuppiah ${ }^{1 *}$, S. Muthubalaji ${ }^{2}$, S. Ravivarman ${ }^{3}$, Md. Asif $^{4}$, Abhishek Mandal $^{5}$ \\ ${ }^{1,3,4}$ Associate Professor, Department of Electrical and Electronics Engineering, Vardhaman College of Engineering, Shamshabad, \\ Telangana, India \\ ${ }^{2}$ Professor, Department of Electrical and Electronics Engineering, CMR College of Engineering \& Technology, Kandlakoya, Telangana, \\ India \\ ${ }^{5}$ Final Year B.E., Department of Electrical and Electronics Engineering, Vardhaman College of Engineering, Shamshabad, Telangana, \\ India \\ *Corresponding author E-mail:natarajankaruppiah@vardhaman.org
}

\begin{abstract}
Flexible Alternating Current Transmission System devices have numerous applications in electrical transmission lines like improvement of voltage stability, reactive power compensation, congestion management, Available Transfer Capacity enhancement, real power loss reduction, voltage profile improvement and much more. The effectiveness of these FACTS devices is enhanced by the placement of these devices in the transmission lines. The placement is based on transmission line sensitivity factors such as Bus voltage stability index and line voltage stability index. This research article focuses on optimizing the location, number and ratings of FACTS devices u sing Evolutionary Algorithms like Bacterial Foraging Algorithm and Gravitational search algorithm. FACTS devices such as Static Var Compensator, Thyristor Controlled Series Capacitor and Unified Power Flow Controller are placed on IEEE 14 bus and IEEE 30 bus systems for reducing the real power loss in the transmission system. The results show that the performance of the transmission lines is enhanced more using Bacterial Foraging Algorithm than Gravitational Search Algorithm.
\end{abstract}

Keywords: Bacterial Foraging Algorithm, Gravity Search Algorithm, SVC, TCSC, UPFC, Voltage stability.

\section{Introduction}

Present day power systems are facing numerous challenges. The demand for energy is increasing drastically nowadays. This increased power demand is met out by increasing the power generation. There are various means of increasing the power generation. The growth of renewable energy and nuclear energy has increased the power generation to a larger extent [1]. But this power has to reach the end consumers by constructing new transmission lines. The Right of Way and other environmental factors have curtailed the erection of new transmission lines. Therefore the increased power generation has to be transmitted to the end consumers through the existing transmission lines. This increases the loadability of existing transmission lines. Moreover when the transmission lines are overloaded, the problem of voltage stability arises [2]. The voltage profile of the system buses gets affected. Also the real power loss increases. These problems are met out by the placing FACTS devices in the desired locations of the transmission line [3].

The advancement of power electronic semiconductor devices has led to the development of FACTS controllers. These controllers provide ease of power control in transmission lines. FACTS controllers are normally connected in series or parallel to the transmission lines. These controllers enhance the power transfer capability of the existing transmission lines. They also improve the voltage stability of the transmission system. When subjected to external disturbances these controllers help the power system to regain its normal state. Effective reactive power management is done using these controllers in transmission system [4].

In this paper, SVC, TCSC and UPFC of different numbers and ratings are placed at different buses and transmission line branches to improve the voltage stability of the transmission system. The performance of the existing transmission system is improved with these devices. Early researchers have used analytical methods to place these devices in transmission lines. It includes Linear Programming (LP) and Mixed Integer LP [5].

With the development of artificial intelligent techniques and Evolutionary algorithms, researchers have used Particle Swarm Optimization [6], Genetic Algorithm [7], Tabu Search [8] and Neural Networks [9] to place the FACTS devices at the desired locations in transmission line. Later the researchers used sensitivity factors of the transmission system such as Line Voltage Sensitivity Index, Bus Voltage Sensitivity Index and Maximum Power Stability Index to locate these FACTS devices. Nowadays researchers use sensitivity factors technique to locate the FACTS devices at proper locations in the transmission system and optimization techniques to calculate the number and rating of these devices.

This paper proposes a method to place SVC, TCSC and UPFC at desired locations in transmission line to enhance the parameters of transmission system. Sensitivity Analysis technique is used to find out the proper location of the FACTS devices in the transmission system. Optimization algorithm is used to find out the number and rating of these devices. This improves the voltage stability of the system. The algorithms used for this purpose are GSA and BFO algorithms. BFOA and GSA are known to solve effectively largescale nonlinear optimization problems. BFO algorithm works on 
the behaviour of E. coli bacteria and GS algorithm works on the basis of mass and gravity. The proposed approaches have been tested on IEEE 14-bus and IEEE 30-bus systems and the results are presented. The test results show that the sizing of the FACTS devices identified by BFOA gives improved performance than that of GSA.

The paper is organized as follows: Section 1 describes about the present scenario of transmission system and the literature that has described about the losses and voltage stability. Section 2 explains about the modelling of SVC, TCSC and UPFC. Section 3 portrays about the stability indices. Section 4 describes about the problem formulation. Section 5 and 6 explains the BFO and GSA optimization algorithms. Section 7 discusses about the results obtained. Section 8 concludes the research work.

\section{Modeling of FACTS Devices}

In this section SVC, TCSC and UPFC are modelled as variable susceptance, variable inductance, variable capacitance or a combination of variable inductance and capacitance.

\subsection{Modeling of SVC}

Static Var Compensator (SVC) is connected in parallel to the transmission system and is modeled as a variable susceptance [12] as shown in Fig. 1 with the rating of

$B_{s v c}^{\min } \leq B_{s v c} \leq B_{s v c}^{\max }$

where

$B_{s v c}^{\text {min }}$ - Minimum susceptance value of SVC

$B_{s v c}^{\max }$ - Maximum susceptance value of SVC

$B_{s v c}$ - Increase or Decrease in Bus Susceptance value due to the addition of SVC susceptance

The power flow in the transmission line is controlled by varying the susceptance of SVC.
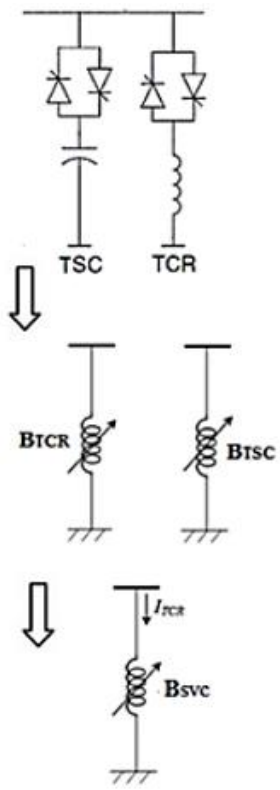

Fig. 1: Steady-state model of SVC

\subsection{Modeling of TCSC}

TCSC is characterized as variable impedance [12] as illustrated in Fig. 2 with the rating of
$-0.8 X_{L} \leq X_{T C S C} \leq 0.2 X_{L} p u$

where

$X_{T C S C^{-}}$Increase or decrease in Transmission line reactance due to TCSC

$X_{L^{-}}$Transmission Line Reactance where TCSC is connected

By changing the reactance of the TCSC the overall impedance of the transmission line is varied. This action of TCSC controls the power flow. TCSC is operated in inductive or capacitive mode to improve the voltage stability of the transmission line [13].

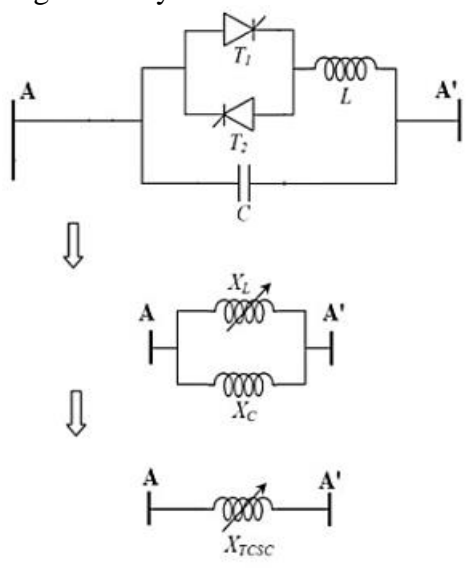

Fig. 2: Steady-state model of TCSC

\subsection{Modeling of UPFC}

In this paper, UPFC is considered as a combination of SVC and TCSC and it is modeled [14-15] with the rating as mentioned in equation (1) and (2).

\section{Stability Indices}

In modern day power systems, Bus stability indices are used to assess the stability and performance of the transmission system. If the bus voltages are within the desired permissible values then it is said to be stable. BVSI is the index used to assess the stability of buses and LVSI is the index used to assess the stability of the branches of the transmission line. [16].

\subsection{Line Voltage Stability Index (LVSI)}

LVSI is represented by the equation

$$
L_{m n}=\frac{4 X_{n} Q_{n}}{\left(V_{m} \sin \left(\theta_{m n}-\delta_{m}\right)\right)^{2}}
$$

where

$V_{m}$ - Voltage magnitude at sending end

$Q_{n}$ - Reactive power magnitude at receiving end

$X_{n}$ - Reactance magnitude at receiving end

$\theta_{m n}$ - Impedance angle in degrees

$\delta_{m^{-}}$- Angle difference between the sending end voltage and the receiving end voltage.

\subsection{Bus Voltage Stability Index (BVSI)}

BVSI is computed as

$L_{j}=\left|1-\sum_{i=1}^{g} F_{j i} \frac{v_{i}}{v_{j}}\right|$

where 
$j=g+1 \ldots . . N$, total number of buses

$g$ - Number of generators connected to the system.

The values of $F_{i j}$ are obtained from $\mathrm{Y}$ bus matrix.

$F_{i j}=\left[Y_{L L}\right]^{-1}\left[Y_{L G}\right]$

where $Y_{L L}$ and $Y_{L G}$ are partitioned portions of the Y-bus matrix.

\section{Problem Formulation}

The objective of this paper is to find the suitable rating of FACTS devices with minimized real power loss, improved voltage profile and enhanced voltage stability and is given by

$$
\min f=\sum_{l=1}^{n} P_{L}^{l}+\sum_{i=1}^{n-g} V_{D_{i}}+\sum_{j=1}^{n-g} L_{j}
$$

where

$P_{L}^{l}$ - Real power in a line $l$

$V_{D_{i}}$ - Voltage deviation of load bus i, which is given by,

$V_{D_{i}}=\left(1-V_{i}\right)^{2}$

where

$V_{i^{-}}$Voltage at bus $i$

$L_{j}$ - Bus Voltage Stability Index (BVSI) of load bus $j$

\subsection{Real Power and Bus Voltage Constraints}

$$
J=\Pi_{L I N E} O V L_{\text {LINE }} \times \Pi_{B U S} V S_{B U S}
$$

where

$\begin{array}{lll}\text { J } & - & \text { violation factor } \\ \text { OVL } & - & \text { line overload factor } \\ \text { VS } & - & \text { voltage stability index for a bus. }\end{array}$

$O V L=\left\{\begin{array}{c}1 ; \quad \text { if } P_{p q} \leq P_{p q}^{\max } \\ e^{\left(\mu \mid 1-\frac{P_{p q}}{P_{p q}^{\max }}\right)} ; \text { if } P_{p q}>P_{p q}^{\max }\end{array}\right.$

$V S= \begin{cases}1 & ; \text { if } 0.9 \leq V_{b} \leq 1.1 \\ e^{\left(\lambda\left|1-V_{b}\right|\right)} & ; \quad \text { otherwise }\end{cases}$

where

$P_{p q} \quad$ - Active power which flows between $\mathrm{p}$ and $\mathrm{q}$

$P_{p q}^{\max }$ - Transmission lines Thermal limit between buses $p$ and $q$

$V_{b} \quad$ - Voltage at bus $b$

$\lambda$ and $\mu$ - Positive constants and both are equal to 0.1

\section{Gravitational Search Algorithm}

GSA is a bio inspired algorithm that works on the law of motion and gravity. In this algorithm, a set of objects with their masses are used by the law of gravity and motion for searching the optimal solution. The procedure of the searching process has been discussed as below [17, 18]:

Step 1: For a system with 'N' agents called objects, mass of the $i^{\text {th }}$ agent is found to be
$X_{i}=\left\{x_{i}^{1}, \ldots, x_{i}^{d}, \ldots, x_{i}^{n}\right\}$

where

$x_{i}^{d}$ - position of $i^{\text {th }}$ mass, and

$n$ - dimension of the considered problem.

Step 2: Fitness value has been evaluated for all the agents and sorted. Among all the agents, the best and worst agents have been identified with the measure of fitness value.

$\operatorname{best}(t)=\min$ fit $_{i}(t)$

worst $(t)=\max$ fit $_{i}(t)$

where

fit $_{i}(t)$ - fitness value of $i^{\text {th }}$ agent at time $t$

Step 3: The gravitational constant $G(t)$ has been computed by the following function at time $\mathrm{t}$,

$G(t)=G_{0} e^{-\alpha \frac{t}{T}}$

where

$G_{0}$ - initial value.

Step 4: Mass of every agent has been updated using

$m_{i}(t)=\frac{\operatorname{fit}_{i}(t)-\operatorname{worst}(t)}{\operatorname{best}(t)-\operatorname{worst}(t)}$

$M_{i}(t)=\frac{m_{i}(t)}{\sum_{k=1}^{N} m_{k}(t)}$

Step 5: Force exerted on the $\mathrm{i}^{\text {th }}$ mass has been found with the law of gravity as,

$$
\begin{aligned}
F_{i}^{d}(t)= & \sum_{j=k_{\text {best }}, j \neq 1}^{N} \operatorname{rand}_{j} G(t) \frac{M_{j}(t) M_{i}(t)}{\left\|X_{i}(t), X_{j}(t)\right\|_{2}+\varepsilon} \\
& \left(x_{j}^{d}(t)-x_{i}^{d}(t)\right)
\end{aligned}
$$

where

$k_{\text {best }}-$ set of agents with best fitness;

rand $_{j}$ - number generated between 0 and 1 .

$M_{i}(t)$ - gravitational mass with $i$ agents and

$M_{j}(t)$ - gravitational masses with $\mathrm{j}$ agents

$\left\|X_{i}(t), X_{j}(t)\right\|_{2}$ - Euclidian distance from $i^{t h}$ agent to the $j^{t h}$ agent and

$\varepsilon$ - constant.

Step 6: Acceleration of an agent has been determined from,

$a_{i}^{d}(t)=\frac{F_{i}^{d}(t)}{M_{i}(t)}$

Step 7: Velocity and the position of every agent are updated finally with, 


$$
\begin{aligned}
& V_{i}^{d}(t+1)=\operatorname{rand}_{i} \times V_{i}^{d}(t)+\alpha_{i}^{d}(t) \\
& x_{i}^{d}(t+1)=x_{i}^{d}(t)+V_{i}^{d}(t+1)
\end{aligned}
$$

Step 8: Execution stops once the stopping criterion is met.

\section{Bacterial Foraging Optimization}

The Bacterial Foraging Optimization Algorithm (BFOA) mimics the foraging character exhibited by the bacteria called E. coli. BFOA applies the Darwin's Survival of fittest as other bioinspired optimization algorithm. Here the bacteria with poor foraging strategies are eliminated after many generations, while leaving the bacteria that possess the best foraging approach to survive. This algorithm has four important steps [19].

\section{Step 1: Chemotaxis}

In this step the bacteria has the tendency to move in the direction of nutrient rich food and avoids noxious stuff. The movement is given by the expression

$$
\theta^{i}(j+1, k, l)=\theta^{i}(j, k, l)+C(i) \frac{\Delta(i)}{\sqrt{\Delta^{T}(i) \square \Delta(i)}}
$$

where $\theta^{i}(j, k, l)$ in which

$i$ - bacterium

$j$ - Chemotaxis step

$k$ - reproductive step and

$l$ - elimination-dispersal step

$C(i)$ - size of unit step taken in the random direction

$\Delta(i)$ - randomly generated unit vector

Step 2: Swarming

In this step the cells release an attracting substance called aspartate which attracts other cells towards the main cell and it forms concentric patterns and is moving towards the rich nutrient site. The attracting and repelling property between the cells and the transfer of signals from cell to cell is determined using

$$
\begin{aligned}
J_{c c} & (\theta(i, j, k, l))=\sum_{i=1}^{S} J_{c c}\left(\theta, \theta^{i}(i, j, k, l)\right) \\
= & \sum_{i=1}^{S}\left[-d_{\text {attracant }} \exp \left(-w_{\text {attracant }} \sum_{m=1}^{p}\left(\theta_{m}-\theta_{m}^{i}\right)^{2}\right)\right] \\
+ & \sum_{i=1}^{S}\left[-h_{\text {repellant }} \exp \left(-w_{\text {repellant }} \sum_{m=1}^{p}\left(\theta_{m}-\theta_{m}^{i}\right)^{2}\right)\right]
\end{aligned}
$$

where,

$J_{c c}\left(\theta, \theta^{i}(i, j, k, l)\right)$ - value to be added to the actual objective function $S$ - population size with number of bacteria

$P$ - number of variables to be optimized,

$\theta$ is $\left[\theta_{1}, \theta_{2}, \ldots, \theta_{p}\right]^{T}$ - point in the P-dimensional search domain.

$d_{\text {attractant }}, w_{\text {attractant }}, h_{\text {repellant }}$ and $w_{\text {repellant }}{ }^{-}$coefficients

Step 3: Reproduction

In this process, health of ith bacterium is computed with equation (25).

$$
J_{\text {health }}^{i}=\sum_{j=1}^{N_{c}+1} J^{i}(j, k, l)
$$

The half of the population, which has least healthy bacteria are being removed. Each of the healthier bacteria splits up into two and then occupies the same position to make the population size the same.

Step 4: Elimination and dispersal
Elimination is the process at which the bacteria in the nutrient region is got killed due to the sudden increase in temperature. Dispersal is the process in which some bacteria got dispersed after a number of reproductive events. This step is essential for ensuring the bacteria not to get trapped in local solution.

\section{Results and Discussion}

The performance of the proposed method was analyzed using MATLAB and their results were presented.

\subsection{Base Case Results}

The IEEE-14 bus system and IEEE-30 bus system were used as test systems. The load flow is performed on both test systems using Newton Raphson load flow analysis. [20].

The real power loss and BVSI index was calculated for both the test systems without FACTS devices and is tabulated in Table 1 and 2 respectively.

Table 1: Total Real power loss and BVSI index for IEEE 14 bus system without FACTS devices (base case)

\begin{tabular}{|c|c|c|}
\hline \multirow{2}{*}{ Sl. No } & \multicolumn{2}{|c|}{ Without FACTS devices } \\
\cline { 2 - 3 } & Real Power loss (MW) & BVSI \\
\hline 1. & 13.593 & 10.2139 \\
\hline
\end{tabular}

Table 2: Total Real power loss and BVSI index for IEEE 30 bus system without FACTS devices (base case)

\begin{tabular}{|c|c|c|}
\hline \multirow{2}{*}{ Sl. No } & \multicolumn{2}{|c|}{ Without FACTS devices } \\
\cline { 2 - 3 } & Real Power loss (MW) & BVSI \\
\hline 1. & 17.528 & 26.2732 \\
\hline
\end{tabular}

\subsection{Suitable location of FACTS Devices using BVSI and LVSI}

The LVSI was calculated for all the branches and they were ranked in the descending order. The top 5 ranks are shown in Table 3. These branches are the suitable branches in which series FACTS devices are placed. Similarly BVSI was calculated for all the buses and they were ranked in the descending order. The top 5 ranks are shown in Table 4. These buses are the suitable buses in which shunt FACTs devices are placed.

Table 3: Ranking of LVSI for TCSC and UPFC

\begin{tabular}{|c|c|c|c|c|}
\hline \multirow{2}{*}{ Rank } & \multicolumn{2}{|c|}{ IEEE-14 bus system } & \multicolumn{2}{c|}{ IEEE-30 bus system } \\
\cline { 2 - 5 } & Branch No & LVSI & Branch No & LVSI \\
\hline 1 & 10 & 0.2658 & 15 & 0.2253 \\
\hline 2 & 8 & 0.1458 & 11 & 0.1746 \\
\hline 3 & 14 & 0.1430 & 12 & 0.1529 \\
\hline 4 & 9 & 0.0880 & 13 & 0.1304 \\
\hline 5 & 1 & 0.0715 & 36 & 0.0775 \\
\hline
\end{tabular}

Table 4: Ranking of BVSI for SVC

\begin{tabular}{|c|c|c|c|c|}
\hline \multirow{2}{*}{ Rank } & \multicolumn{2}{|c|}{ IEEE-14 bus system } & \multicolumn{2}{c|}{ IEEE-30 bus system } \\
\cline { 2 - 5 } & Bus No & BVSI & Bus No & BVSI \\
\hline 1 & 12 & 0.9797 & 12 & 0.9706 \\
\hline 2 & 13 & 0.9796 & 9 & 0.9704 \\
\hline 3 & 11 & 0.9796 & 16 & 0.9703 \\
\hline 4 & 7 & 0.9796 & 10 & 0.9702 \\
\hline 5 & 9 & 0.9793 & 14 & 0.9702 \\
\hline
\end{tabular}

\subsection{Suitable sizing and rating of FACTS devices using BFOA and GSA}

After finding suitable location of FACTS devices, suitable rating of FACTS devices is obtained using BFOA and GSA. The desired placement of SVC, TCSC or UPFC with their count and rating are obtained from BFOA and GSA for both the test systems and are tabulated in Table 5 and Table 6 respectively. Since UPFC is a combination of series and shunt FACTS devices while placing UPFC the rating of both series and shunt components are found out. Five and seven cases are considered for the combination of 
FACTS devices in IEEE 14 bus test system and IEEE 30 bus test system respectively. The desired sizing, number and placing are obtained for both the test systems using GS and BFO algorithms.

Table 5: Suitable sizing and rating of multi-type facts devices in IEEE-14 bus system

\begin{tabular}{|c|c|c|c|c|c|c|}
\hline \multirow[t]{2}{*}{ Case } & \multirow{2}{*}{$\begin{array}{c}\text { Multi } \\
\text { type } \\
\text { FACTS } \\
\text { devices } \\
\text { count }\end{array}$} & \multirow{2}{*}{$\begin{array}{c}\text { Name } \\
\text { of } \\
\text { FACTS } \\
\text { device }\end{array}$} & \multirow{2}{*}{$\begin{array}{c}\text { Individual } \\
\text { FACTS } \\
\text { Count }\end{array}$} & \multirow{2}{*}{$\begin{array}{l}\text { Location } \\
\text { (Br - } \\
\text { Branch) }\end{array}$} & GSA & $\mathrm{BFOA}$ \\
\hline & & & & & $\begin{array}{c}\text { Rating } \\
\text { (pu) }\end{array}$ & $\begin{array}{c}\text { Rating } \\
\text { (pu) }\end{array}$ \\
\hline \multirow{3}{*}{ I } & \multirow{3}{*}{3} & TCSC & 1 & $\mathrm{Br}-10$ & -0.072 & -0.122 \\
\hline & & SVC & 1 & Bus-12 & 0.007 & -0.775 \\
\hline & & UPFC & 1 & $\mathrm{Br}-10$ & $\begin{array}{r}-0.549 \\
0.506\end{array}$ & $\begin{array}{l}-0.571 \\
-0.541\end{array}$ \\
\hline \multirow{3}{*}{ II } & \multirow{3}{*}{4} & TCSC & 2 & $\begin{array}{c}\mathrm{Br}-10 \\
\mathrm{Br}-8\end{array}$ & $\begin{array}{r}-0.165 \\
0.057\end{array}$ & $\begin{array}{l}-0.542 \\
-0.398\end{array}$ \\
\hline & & SVC & 1 & Bus-12 & 0.840 & -0.758 \\
\hline & & UPFC & 1 & $\mathrm{Br}-10$ & $\begin{array}{c}-0.611 \\
0.126\end{array}$ & $\begin{array}{l}-0.398 \\
-0.864\end{array}$ \\
\hline \multirow{4}{*}{ III } & \multirow{4}{*}{4} & TCSC & 1 & $\mathrm{Br}-10$ & -0.188 & -0.192 \\
\hline & & SVC & 1 & Bus-12 & 0.867 & -0.183 \\
\hline & & \multirow{2}{*}{ UPFC } & \multirow{2}{*}{2} & $\mathrm{Br}-10$ & $\begin{array}{r}-0.176 \\
0.187 \\
\end{array}$ & $\begin{array}{l}-0.607 \\
-0.846 \\
\end{array}$ \\
\hline & & & & $\mathrm{Br}-8$ & $\begin{array}{l}-0.458 \\
-0.016 \\
\end{array}$ & $\begin{array}{l}-0.777 \\
-0.601 \\
\end{array}$ \\
\hline \multirow{3}{*}{ IV } & \multirow{3}{*}{4} & SVC & 2 & $\begin{array}{l}\text { Bus-12 } \\
\text { Bus-13 } \\
\end{array}$ & $\begin{array}{r}-0.627 \\
0.185 \\
\end{array}$ & $\begin{array}{r}0.590 \\
-0.463 \\
\end{array}$ \\
\hline & & \multirow{2}{*}{ UPFC } & \multirow[b]{2}{*}{2} & $\mathrm{Br}-10$ & $\begin{array}{r}-0.033 \\
0.112 \\
\end{array}$ & $\begin{array}{r}-0.073 \\
-0.872 \\
\end{array}$ \\
\hline & & & & Br-8 & $\begin{array}{c}-0.773 \\
0.788 \\
\end{array}$ & $\begin{array}{l}-0.308 \\
-0.604 \\
\end{array}$ \\
\hline \multirow{2}{*}{ V } & \multirow[b]{2}{*}{4} & TCSC & 2 & $\begin{array}{c}\mathrm{Br}-10 \\
\mathrm{Br}-8\end{array}$ & $\begin{array}{l}-0.044 \\
-0.067\end{array}$ & $\begin{array}{l}-0.608 \\
-0.376\end{array}$ \\
\hline & & SVC & 2 & $\begin{array}{l}\text { Bus-12 } \\
\text { Bus-13 }\end{array}$ & $\begin{array}{l}0.003 \\
0.512\end{array}$ & $\begin{array}{l}-0.288 \\
-0.874\end{array}$ \\
\hline
\end{tabular}

The effects of various combinations of FACTS devices i.e., difference in real power with and without FACTS devices are obtained for both the test systems and are tabulated in Table 7 and Table 8 respectively. The percentage real power loss reduction was also calculated for each case in both the test systems. Among various cases case III (1 TCSC, 1 SVC and 2 UPFC) was the best for IEEE 14 bus test system since the percentage power loss reduction was more in this case $(64.98 \%$ from GSA and $75.59 \%$ from BFOA). This real power loss reduction percentage for IEEE 14 bus system for all possible cases is represented using bar chart in Fig. 3.

Table 6: Suitable sizing and rating of multi-type facts devices in IEEE-30 bus system

\begin{tabular}{|c|c|c|c|c|c|c|}
\hline \multirow[t]{2}{*}{ Case } & \multirow{2}{*}{$\begin{array}{c}\text { Multi } \\
\text { type } \\
\text { FACTS } \\
\text { devices } \\
\text { count }\end{array}$} & \multirow{2}{*}{$\begin{array}{c}\text { Name } \\
\text { of } \\
\text { FACTS } \\
\text { device }\end{array}$} & \multirow{2}{*}{$\begin{array}{c}\text { Individual } \\
\text { FACTS } \\
\text { Count }\end{array}$} & \multirow{2}{*}{$\begin{array}{l}\text { Location } \\
\text { (Br - } \\
\text { Branch) }\end{array}$} & GSA & $\mathrm{BFOA}$ \\
\hline & & & & & $\begin{array}{c}\text { Rating } \\
(\mathrm{pu})\end{array}$ & $\begin{array}{l}\text { Rating } \\
\text { (pu) }\end{array}$ \\
\hline \multirow{3}{*}{ I } & \multirow{3}{*}{3} & TCSC & 1 & $\mathrm{Br}-15$ & 0.126 & 0.106 \\
\hline & & SVC & 1 & Bus-12 & -0.306 & -0.842 \\
\hline & & UPFC & 1 & Br-15 & $\begin{array}{l}-0.042 \\
-0.213 \\
\end{array}$ & $\begin{array}{c}-0.544 \\
0.802 \\
\end{array}$ \\
\hline \multirow{3}{*}{ II } & \multirow{3}{*}{4} & TCSC & 2 & $\begin{array}{l}\mathrm{Br}-15 \\
\mathrm{Br}-11\end{array}$ & $\begin{array}{l}0.502 \\
0.029\end{array}$ & $\begin{array}{l}-0.743 \\
-0.438\end{array}$ \\
\hline & & SVC & 1 & Bus-12 & 0.747 & -0.790 \\
\hline & & UPFC & 1 & $\mathrm{Br}-15$ & $\begin{array}{l}-0.615 \\
-0.357 \\
\end{array}$ & $\begin{array}{l}-0.012 \\
-0.894 \\
\end{array}$ \\
\hline \multirow{3}{*}{ III } & \multirow{3}{*}{5} & TCSC & 2 & $\begin{array}{l}\mathrm{Br}-15 \\
\mathrm{Br}-11\end{array}$ & $\begin{array}{l}-0.128 \\
-0.176\end{array}$ & $\begin{array}{l}0.157 \\
0.150\end{array}$ \\
\hline & & SVC & 2 & $\begin{array}{c}\text { Bus-12 } \\
\text { Bus-9 }\end{array}$ & $\begin{array}{l}0.679 \\
0.060\end{array}$ & $\begin{array}{l}-0.630 \\
-0.878\end{array}$ \\
\hline & & UPFC & 1 & $\mathrm{Br}-15$ & $\begin{array}{r}-0.230 \\
0.416 \\
\end{array}$ & $\begin{array}{r}-0.539 \\
-0.234 \\
\end{array}$ \\
\hline \multirow{3}{*}{ IV } & \multirow{3}{*}{4} & SVC & 2 & $\begin{array}{c}\text { Bus-12 } \\
\text { Bus-9 }\end{array}$ & $\begin{array}{l}-0.339 \\
-0.728 \\
\end{array}$ & $\begin{array}{l}-0.493 \\
-0.657 \\
\end{array}$ \\
\hline & & \multirow{2}{*}{ UPFC } & \multirow[b]{2}{*}{2} & $\mathrm{Br}-15$ & $\begin{array}{c}-0.682 \\
0.121 \\
\end{array}$ & $\begin{array}{l}-0.419 \\
-0.435 \\
\end{array}$ \\
\hline & & & & $\mathrm{Br}-11$ & $\begin{array}{l}-0.196 \\
-0.217 \\
\end{array}$ & $\begin{array}{l}-0.588 \\
-0.779 \\
\end{array}$ \\
\hline
\end{tabular}

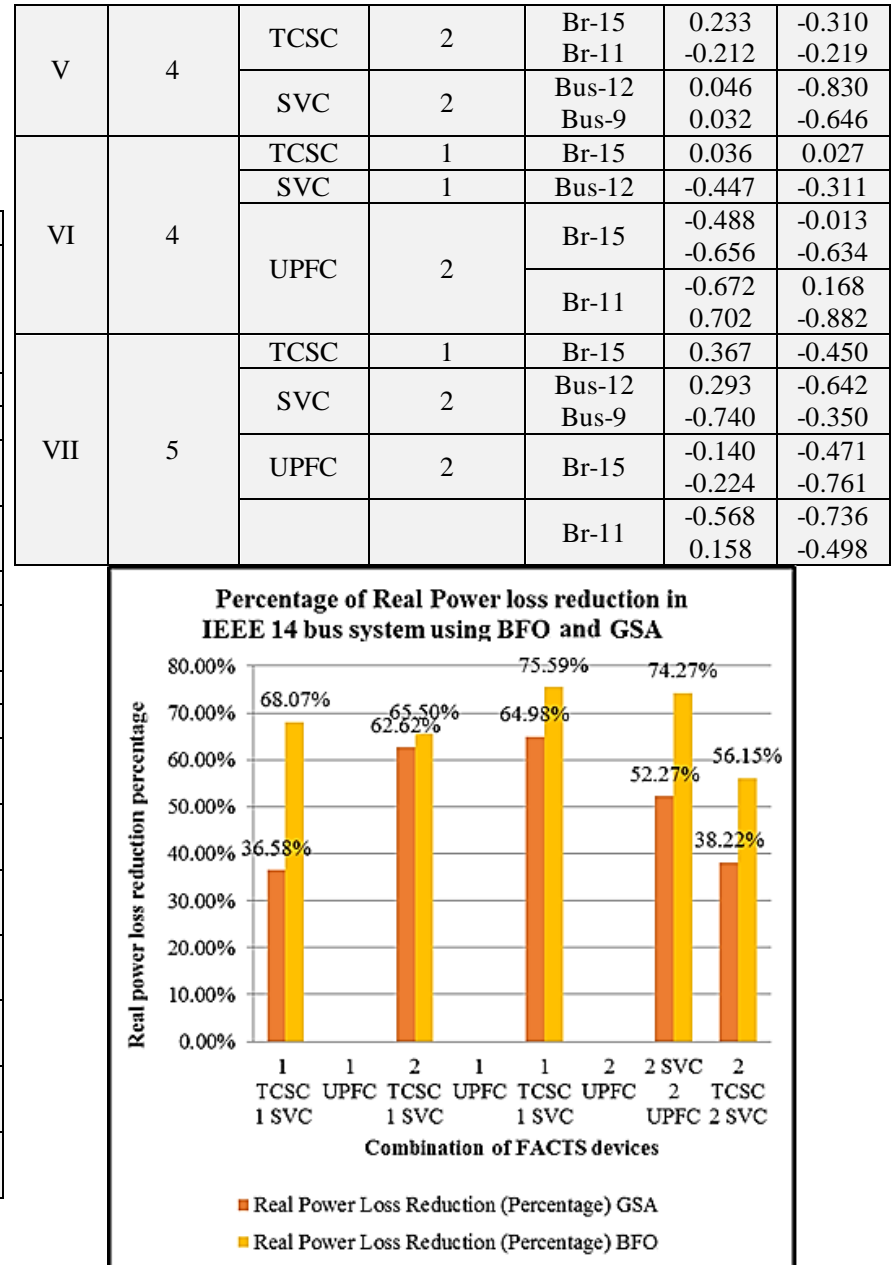

Fig. 3: Real power loss reduction percentage in IEEE 14 bus system using GSA and BFOA

Table 7: Effect of multi-type FACTS devices in IEEE-14 bus system

\begin{tabular}{|c|c|c|c|c|}
\hline \multirow{2}{*}{$\begin{array}{c}\text { Case } \\
\text { No }\end{array}$} & $\begin{array}{c}\text { Difference in } \\
\text { Real power } \\
\text { loss with and } \\
\text { without } \\
\text { FACTS(MW) }\end{array}$ & $\begin{array}{c}\text { Percentage } \\
\text { Real Power } \\
\text { Loss Reduc- } \\
\text { tion }\end{array}$ & $\begin{array}{c}\text { Active } \\
\text { power loss } \\
\text { reduction } \\
\text { (MW) }\end{array}$ & $\begin{array}{c}\text { Percentage } \\
\text { Real Power } \\
\text { Loss Reduc- } \\
\text { tion }\end{array}$ \\
\hline I & 4.9704 & 36.58 & 9.2484 & 68.07 \\
\hline II & 8.5079 & 62.62 & 8.9001 & 65.50 \\
\hline III & $\mathbf{8 . 8 2 8 7}$ & $\mathbf{6 4 . 9 8}$ & $\mathbf{1 0 . 2 0 7 1}$ & $\mathbf{7 5 . 5 9}$ \\
\hline IV & 7.1019 & 52.27 & 10.0914 & 74.27 \\
\hline V & 5.1932 & 38.22 & 7.6288 & 56.15 \\
\hline
\end{tabular}

The real power loss reduction percentage is calculated with respect to the base case. The percentage is obtained using the formula: Percentage real power loss reduction $=($ Real power loss obtained for base case - Real power loss obtained for that particular case)/Real power loss obtained for base case.

\begin{tabular}{c|c|c|c|c|}
\multicolumn{4}{c}{ Table 8: Effect of multi-type FACTS devices in IEEE-30 bus system } \\
\begin{tabular}{|c|c|c|c|} 
Case \\
No
\end{tabular} & $\begin{array}{c}\text { Active pow- } \\
\text { er loss reduc- } \\
\text { tion } \\
\text { (MW) }\end{array}$ & $\begin{array}{c}\text { Percentage } \\
\text { Real Power } \\
\text { Loss Reduc- } \\
\text { tion }\end{array}$ & $\begin{array}{c}\text { Active power } \\
\text { loss reduc- } \\
\text { tion } \\
\text { (MW) }\end{array}$ & $\begin{array}{c}\text { Percentage } \\
\text { Real Power } \\
\text { Loss Re- } \\
\text { duction }\end{array}$ \\
\hline I & 5.3724 & 30.6 & 12.6233 & 72.02 \\
\hline II & 5.3464 & 30.5 & 12.4091 & 70.8 \\
III & 5.5992 & 31.9 & 13.0664 & 74.55 \\
\hline IV & 7.3594 & 41.9 & 13.0899 & 74.68 \\
\hline V & 6.9326 & 39.5 & 12.5342 & 71.51 \\
\hline VI & $\mathbf{9 . 7 1 7 8}$ & $\mathbf{5 5 . 4 4}$ & $\mathbf{1 3 . 2 5 1}$ & $\mathbf{7 5 . 6 0}$ \\
\hline VII & 9.9208 & 56.6 & 12.9008 & 73.6 \\
\hline
\end{tabular}

Among various cases case VI (1 TCSC, 1 SVC and 2 UPFC) was the best for IEEE 30 bus test system since the percentage power loss reduction was more in this case $(55.44 \%$ from GSA and $75.60 \%$ 
from BFOA). This real power loss reduction percentage for IEEE 30 bus system for all possible cases is represented using bar chart in Fig. 4.

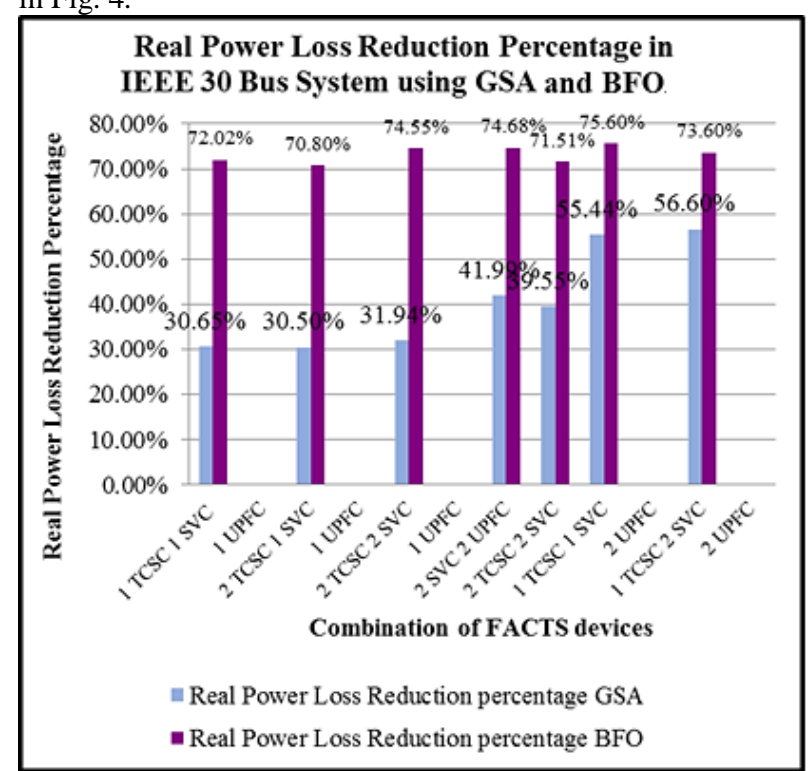

Fig. 4: Real power loss reduction percentage in IEEE 14 bus system using GSA and BFOA

\section{Conclusion}

In this paper, SVC, TCSC and UPFC are placed at the desired location of the transmission lines to reduce the real power loss in the transmission system. By reducing the real power loss, voltage stability of the transmission system is ensured and the performance of the transmission lines is enhanced. The various combination of FACTS devices and their rating and placement were found out using GSA and BFOA algorithms. The performance of the two algorithms was also compared. BFO algorithm performed better than GSA algorithm since the real power loss reduction is more in this case. The placement of the FACTS devices were based on sensitivity indices namely LVSI and BVSI. Therefore this paper has used both sensitivity factors and optimization algorithm approach to enhance the performance of transmission system.

\section{References}

[1] Islam, M.A., Hasanuzzaman, M, Rahim, N.A., Nahar, A and Hosenuzzaman, M., "Global Renewable Energy-Based Electricity Generation and Smart Grid System for Energy Security", The Scientific World Journal, vol. 2014, Article ID 197136, 13 pages, 2014. doi:10.1155/2014/197136

[2] Sauer, P.W., Lesieutre, B.C., Pai, M.A., "Maximum loadability and voltage stability in power systems", International Journal of Electrical Power \& Energy Systems, vol. 14, no. 3, pp.145-153, 1993.

[3] Gaur, D. and Mathew, L., "Optimal placement of FACTS devices using optimization techniques: A review", 3rd International Conference on Communication Systems (ICCS-2017), IOP Publishing, pp.1-15.

[4] Song, S.H., Limb, J.U and Seung-II Moon, "Installation and operation of FACTS devices for enhancing steady-state security", Electric Power Systems Research, vol.70, 2004, pp. 7-15.

[5] Chang, R.W. and Saha, T.K., "Maximizing power system loadability by optimal allocation of SVC using mixed integer linear programming," IEEE Power and Energy Society General Meeting, Jul.25-29, 2010, pp. 1-7.

[6] Azadani E.N, Hosseinian S.H, and Hasanpor P, "Optimal placement of multiple STATCOM for voltage stability margin enhancement using particle swarm optimization, Electrical Engineering, Springer, Vol. 90, issue 7, pp.503-510.

[7] Tiwari P K, and Sood Y R," Optimal location of FACTS devices in power system using Genetic Algorithm", World Congress on Nature and Biologically Inspired Computing (NaBlC), 2009, pp. 10341040 .
[8] Mori H, Goto Y, "A parallel tabu search based method for determining optimal allocation of FACTS in power systems. IEEE International conference on power system technologies, 2000, pp.10771082.

[9] Modi, P.K, Singh, S.P and Sharma, J.D., "Voltage stability evaluation of power system with FACTS devices using fuzzy neural network", Engineering Applications of Artificial Intelligence, Elsevier, Vol.20, no. 4, 2007, pp. 481-491.

[10] Esmin, A.A.A., Torres, G., de Souza, A.C.Z. "A hybrid particle swarm optimization applied to loss power minimization", IEEE Transactions on Power System, Vol.20, no.2, 2005, pp.859-866.

[11] Lin W.M, Lu K.H, Huang C. H, Ou T.C and Li Y.H, "Optimal location and capacity of STATCOM for voltage stability enhancement using ACO plus GA" IEEE/ASME International Conference on Advanced Intelligent Mechatronics Suntec Convention and Exhibition Center Singapore, July 14-17, 2009, pp.1915.1920.

[12] Mohammed Osman Hassan, S. J. Cheng, Senior, Zakaria Anwar Zakaria "Steady-State Modeling of SVC and TCSC for Power Flow Analysis" Proceedings of the International MultiConference of Engineers and Computer Scientists 2009, Hong Kong, Vol II, 2009.

[13] Noroozian M, Angquist L, Ghandhari M, Anderson G "Improving Power System Dynamics by Series-Connected Facts Devices", IEEE Transactions on Power Delivery, Vol. 12, No. 4, 1997, pp.1635-1641.

[14] Canlzares C.A and Faur Z.T, "Analysis of SVC and TCSC controllers in voltage collapse," IEEE Transactions on Power system, Vol. 14, no 1, 1999, pp.158-165.

[15] Misao Kimura, Choei Takahashi, HidetoKishibe, Yasuyuki Miyazaki, Yasuhiro Noro, and Naotakalio "Modeling and Real-Time Simulation of UPFC" Electrical Engineering in Japan, Vol. 155, No. 1, 2006, pp.19-26.

[16] N Karuppiah, V Malathi, G Selvalakshmi, "Optimal Placement and Sizing of Multi-type Facts Devices Using PSO and HSA", International Conference on Swarm, Evolutionary, and Memetic Computing, 2014, 292-303

[17] Esmat Rashedi Hossein Nezambadi pour, Saeid saryazdi, "GSA: A Gravitational Search Algorithm", Information Sciences, vol. 179, no. 13, June 2009, pp. 2232-2248.

[18] N Karuppiah, V Malathi, S Priyadevi, "Optimal Placement and Sizing of Multi Type FACTS Devices in Deregulated Environment for ATC Enhancement using Gravitational Search Algorithm, International Journal of Applied Engineering Research, vol. 10, no. 5, pp. 4404-4409, 2015.

[19] S. Das and A. Biswas and S. Dasgupta and A. Abraham, "Bacterial Foraging Optimization Algorithm: Theoretical Foundations, Analysis, and Applications", in Foundations of Computational Intelligence Volume 3: Global Optimization, pages 23-55, Springer, 2009.

[20] H. Amhriz-PBrez, E. Acha, and C. R. Fuerte-Esquivel, "Advanced SVC Models for Newton Raphson Load Flow and Newton Optimal Power Flow Studies," IEEE Transactions On Power Systems, Vol. 15. No. 1, February, 2000, pp. 129-136. 